\title{
Semantic Change of Hijab, Halal and Islamist from Arabic to English
}

\author{
AMJAAD OMAR ALMARWAEY \\ English Language Centre, Umm AlQura University, \\ Makkah, Saudi Arabia \\ UMMUL K. AHMAD \\ Language Academy, Universiti Teknologi Malaysia, \\ Johor Bahru, Malaysia \\ m-ummul@utm.my
}

\begin{abstract}
This paper explores the interrelationship between culture, language and communication. English language has established a position for itself as a widely spoken language in the world in many aspects of people's lives regardless of race, creed or religion. Many Islamic specific terms have been borrowed into English as a result of continuous contact between Muslims and English-speaking communities. This study analyzes the semantic change of three commonly used Islamic terms by English speakers in daily life: hijab, halal, Islamist, and their definitions in English dictionaries. It aims to investigate their definitions and explore their associated meanings both in dictionaries and language in use. The definitions of the terms were compared in two reliable English dictionaries, Collins English Dictionary (CED) and Oxford Learner's Dictionary (OLD). A well-known Arabic dictionary, Al Mu 'jam Alwasit Dictionary (AAD), was used for reference of the original Arabic meaning. The Intelligent Web corpus ( $i W e b)$ was used to provide information on the use of the examined terms in daily language, and the words they collocate with. The study adopts a semantic change framework for data analysis. Findings of the research suggest that all three terms have undergone semantic changes, and their new meanings in English do not include the extra levels of social and religious meanings as in the original Arabic language. In particular, the term Islamist has developed negative connotations. Language in use has a strong influence on connotations associated to culture-specific terms.
\end{abstract}

Keywords: Islamic terms; Semantic change; Meaning connotations; Cross-culture loanwords

\section{INTRODUCTION}

Language as an essential tool for human communication is the product of continuous contact between its speakers. It is quite clear that language goes through several changes over time, and it is continuously changing in grammar, words, sounds, and meanings. One of the reasons for this change is the constant interaction between cultures, and movements of people across borders that had always affected languages (Lyons, 1995). However, an important feature of some words is that they are polysemous and have different additional senses, not just one lexical meaning. This is because words adapt and change meaning as a response to the changing needs and demands of the society. In other words, a word or a phrase may have referred to a certain definite entity many centuries ago but could have gained additional layers of meaning or totally change its entire reference with time (Leech, 1981; Cruse, 2000; Katamba, 2005; Liddicoat, 2009).

Language determines the way we perceive the world and imposes this world on our awareness. The way speakers use language reflects their perception of the world and determines their attitudes towards it. Words can also trigger the audience to believe in something for which they do not have full knowledge on. This can be problematic across cultures especially when words carry different values and beliefs, or when a concept may be accepted in one culture but totally rejected in another. Meanings of specific words are intricately connected to values and norms of culture/society from which the words originate, 
and similar values/meanings may not easily be transferred. More specifically, culture as a context may give specific, local meanings to words by adding associated connotations to their standard denotative lexical meaning (Liddicoat, 2009; Hassan, 2016). As Islam grows to be a global religion, many Islamic terms have been borrowed along and adopted by people across cultures, languages and regions, and so often, the terms take on new meanings, somewhat different from their original meanings in Arabic (Hassan, 2016). The semantic change of some Islamic terms borrowed into English particularly makes an interesting study.

\section{ISLAMIC TERMS}

Islamic terms are culture-specific terms that are "particularly related to Islam and Muslims, in the domains of religion, culture, government, society, and way of life" (Ali, 2007, p.32). Newmark (1995) distinguished cultural language from other types of language as referring to specific items that belong to a particular culture. They constitute of terms that refer to concepts specific to the donor language culture but are not present in the recipient culture which are named culture-specific terms (Baker, 2018). The majority of these words have many connotative meanings not just denotative meanings since connotations are closely related to culture, society and history which may in turn pose difficulty in the attempt to retain all the meanings of a term. Nonetheless, this depends on the degree of overlap between the two cultures as well as the knowledge and awareness of the donor culture among the people of the recipient culture.

Although Islamic terms are deeply rooted in Arabic from which they originated, they are used widely by Muslims across different linguistic and cultural backgrounds such as Malay, Indian, Pakistani as well as those from the Western world. Today, English is used by many Muslims as the medium for communication more than any other. It is globally used in a variety of social, academic, professional, commercial contexts. Therefore, it is important to ensure that Islamic terms borrowed into English preserve their original associations in order to achieve successful intercultural communication.

Al-Azzam (2005) has listed some characteristics of Islamic terms which may add to the difficulty in transmitting their meanings. Many Islamic terms are mostly related to the divinity of Islam and thus highly rhetorical; their origin could be tracked to the ancient Arabic language, and they have many layered connotative meanings which makes it difficult to find proper equivalents, even partial ones, in the target language. Some aspects of emotive tones may simply be challenging to convey between largely different cultures. Many terms still retain the majority of their senses and are used in Muslims' daily life today despite the fact that they have originated from more than fourteen centuries ago. Filling this gap of time and place when words are borrowed between languages can simply be difficult (Jasper, 1993).

Arabic terms can also be polysemous, i.e. having more than one sense including the religious meaning. An example is the polysemous lexical item al-kitab (the book) and its plural form al-kutub (the books) as explained by Abdul-Ghafour et al. (2019) having several denotations based on the context in which they occur. This makes the task of finding an equivalent term that carries all of the lexical item's senses more difficult (Dickins et al., 2016).

One of the most significant current discussions in translation related to the Islamic culture is to the way and accuracy of translating the Quran and Hadiths, the sayings of Prophet Mohammad (peace be upon him), and of introducing Islamic terms in English. To deal with the challenges and to fill the linguistic and/or cultural gaps, researchers (e.g. Newmark, 1988; Aldahesh, 2014) have suggested the use of transliteration strategy supported with explanation of the meaning in the target language (see also Ghazala, 2002; Kashgary, 2011). This strategy is defined as "an operation whereby the characters of an alphabetic writing system are 
represented by characters from another alphabetic writing system" (Wright \& Budin, 1997, p. 257). However, the use of transliteration rather than translation, especially in religious or cultural contexts, is assumed to convey an anti-other tone and may have a negative impact on non-Muslim addressees (Davies, 2003) while the use of translated Islamic terms is suggested to be a more favorable option to advocate coexistence and dialogue (El-Shiekh \& Saleh, 2011).

Hassan (2016) has semantically investigated translation versus transliteration strategy of Islamic terms in English in Ibrahim and Johnson-Davies' translation of An-Nawawi's Forty Hadiths in his attempt to explore how well did the authors manage to convey the meaning of Islamic terms into English in their translation. He maintained that transliteration is more appropriate. For example, the term sabr, which the nearest equivalent to in English is patience, is semantically more complex and has a set of meanings depending on its context. This may pose difficulties on translators to choose the right equivalent for each context. As a result, Hassan (2016) and many others (see Ghazala, 2002; Al-Azzam, 2005; Dickins et al., 2016) have maintained that it would be more appropriate if translators retain the Arabic original term. The question is, based on semantic change principles and from language in use perspective, does the use of transliteration strategy guarantees saving culturally specific items from change and meaning distortion? And is it true that knowledge created through language in use has more influence on the meaning of culturally specific items and the conveyed message than lexical knowledge?

Indeed, the volume of terms related to Islam borrowed from Arabic into English is increasing; more and more Muslims now speak English as either a second or a foreign language (Ali, 2007). Nonetheless, researchers believe that coexistence is disturbed between the Islamic culture and other western societies as a result of unnecessary conflict and mutual distrust due to mere linguistic behavior (El-Shiekh \& Saleh, 2011; Baker et al., 2013; Törnberg \& Törnberg, 2016). By and large, Islam and its Muslim followers have been represented in a stereotypical and negative way in western media. Muslims have been described as terrorists, extremists and a threat to people's lives on Facebook, Twitter and other social media (Moore et al., 2008; Awan, 2016; Oboler, 2016).

Numerous studies have investigated culture-specific items and they greatly vary in nature, models and classification, but they are majorly in the context of translation of literary works from and into English (Davies, 2003; Daghoughi \& Hashemian, 2016; Farahani \& Mokhtari, 2016; Öztemel \& Kurt, 2017; Leskovar, 2017). There are also some studies which focused on the translation of Islamic religious texts and/or Islamic religious terms (El-Shiekh \& Saleh, 2011; Agliz, 2015; Alghamdi, 2016; Hassan, 2016; Yulianita et al., 2018). Others studied the representation of Muslims and Islam in the media through analysing associative patterns (Moore et al., 2008; Baker et al., 2013; Törnberg \& Törnberg, 2016). Yet, studies investigating the meanings of borrowed Islamic terms in English remain scarce.

The lexical items chosen for this research, hijab, halal and Islamist, are all related to Islamic culture, and have been borrowed into English in the context of referring to Islam and Muslims. Ali $(2007 ; 2009)$ has provided definitions and sample sentences for the most common Islamic terms and concepts used in English. He provided the following definitions and examples for the terms investigated in this study: "hijab female headscarf, Muslim women who refuse to wear the hijab do not have a proper understanding of Islam." (Ali, 2009, p.84). "Halal permissible in Islam, Muslims need to practice a halal lifestyle, and not focus on halal products alone. Halal income has baraqa, unlike income that is derived in a non-halal manner." (Ali, 2009, p.83). Additionally, Ali (2014) has pointed that the term Islamist is considered as a form of linguistic innovation that resulted from the phenomena of anglicizing Islamic terms through adding English suffixes. Thus, no definition or samples of use have been suggested for the term Islamist. 
These lexical items are regarded as cases considered for thorough analysis rather than representing all Islamic terms. Furthermore, a person who has lived or visited an Englishspeaking country, would have encountered these terms in different mediums of daily communication, such as magazines, news, newspapers and the like. Based on The Intelligent Web corpus (iweb) (Davies, 2018), these terms have the most frequent occurrences in English compared to other terms related to Islam (Simbuka et al., 2019).

\section{ISLAMIC TERMS AND SEMANTIC CHANGE}

The interest in lexical items automatically raises questions about semantic relations that interconnect the various meanings of an item. Lexical items undergo through specific mechanisms of meaning change and adaptation which cause them to take on new meanings, disappear or being borrowed across languages to make them fit better into the recipient language. According to Akidah (2013) and Anwar (2017), semantic change refers to shift or evolution of a word's meaning that usually happens over a period of time, and involves changes in the usage of words to the point where its current meaning is sometimes different from its original meaning.

Meaning of words may also differ from one community to another and from culture to another because speakers have different perspectives in looking at things. Even among the speakers of the same culture, a lexical item may have different connotations (Larson, 1988), such as the term Allah in Arabic that carries different connotations for Muslims than Christians (El-Shiekh \& Saleh, 2011; Yahya, 2018). The assumption that terms in donor language and recipient language have the same referents and senses is not necessarily accurate. Sometimes, even loanwords that have become part of the language's system have other cultural connotations in the recipient language that are not present in the donor language (Hassan, 2016).

Reference is one of the key issues in the use of language that describes the way in which speakers can use words to pick out entities, namely referents, in the world. As a result of the fundamental relationship between meaning and context, Saeed (2015) argues that utterances of the same words may have different meanings in different contexts. Hence, more meaning seems to be communicated rather than explicitly stated. Lyons (1995) claims that unless our emotions about it, understanding of it, knowledge about it have changed, it is possible for the sense of a word to stay unchanged. Emotive meaning is maintained to be more subject to change and is considered to be one of the strongest driving factors in the history of language change. The degree of an expression's emotional or connotative sense relates to the event it arouses in and the type of community experiencing that event. Liddicoat (2009) asserts that the feelings and attitudes of people towards a lexical item can be stimulated by the affective use of particular related expressions. Furthermore, the context in which a specific lexical item occurs will provide the listener or reader with either favorable or unfavorable associations. What can be positive or neutral to a certain readership can carry negative overtones to another. The emotive meaning is therefore connected to the culture or society in which the word occurs.

Many studies have investigated semantic change in Islamic terms borrowed into different languages. A number of studies have examined the semantic change in Arabic loanwords in Bahasa Indonesia. Julul et al. (2019) have found some types of change in meaning. For example, the term alkhuldi in the Arabic language means eternity. Nevertheless, the meaning in the Indonesian language has shifted to mean the prohibited fruit. The term ni'mat which means blessing especially from Allah was extended to mean, satisfied, happy, good or delicious. Puspita and Yusuf (2020) have investigated the semantic change of the two terms jahanam and hijrah in Bahasa Indonesia; the term jahanam means hell in Arabic, however, it 
has been expanded to mean evil or crime and sometimes to describe food. Hijrah means "the departure of Prophet Muhammad from Mecca to Medina with the aim of saving himself and spreading the Islamic teachings" (p. 6), however, its meaning has also been expanded to mean repentance or change in fashion style in Indonesian. The Arabic words borrowed into Kiswahili were also studied by Akidah (2013). The study concluded that lexical borrowing resulted in almost all types of semantic change, i.e., broadening, narrowing, pejoration and amelioration. Danzaki (2015) investigated the semantic change in Arabic loanwords in Hasua, some of which are Islamic terms, and concluded that their meanings have some shifts, such as the term alhaji which originally means a person who has performed pilgrimage in Makkah, but it also expanded to mean a rich man.

\section{PROBLEM STATEMENT}

The purpose of this study is to investigate the semantic change in three terms from the Islamic culture, hijab, halal, Islamist in English. This study starts by looking at the definitions of these terms in English dictionaries, then compare their definitions with an Arabic dictionary and then investigate their communicative context in iWeb (Davies, 2018). The selected terms halal and hijab are highly frequent in everyday English. They have entered the social niche and are used in spoken language as they are related to people's daily activities as shopping and going to restaurants. Islamist is also one of the most frequent terms that is anglicized by adding -ist suffix and occurs mostly in news reports and articles on Islam and Middle Eastern cultures (A1Ajmi \& Al-Otaibi, 2006; Ali, 2014). These terms belong to Newmark's (1995) fourth category in his classification of culturally specific items that includes religious terms, i.e. organizations, custom, activities, procedures, concepts.

Hassan (2016) recommends the use of transliteration strategy for proper nouns, culturespecific terms and partially equivalent words that have the same referents but different connotations in the two languages. He claims that transliteration has the advantage of protecting culture-specific terms, and Islamic terms in particular, from any tampering or interpolation when transferred from the donor language to the recipient language; and it is possible that gradually the transliterated term will become a loanword and be absorbed into the lexicon of the recipient language. Unfortunately, since people's feelings and attitudes towards a term can be influenced by language in use such as in social and news media, transliterations of Islamic religious terms do not necessarily guarantee that these terms would maintain their original meaning from being distorted. Nonetheless, it has been shown that Islamic terms borrowed into English have lost some semantic associations and religious connotations. AlFaruqi (1995) and Ali (2007) indicated four areas of distortions: misspelling, mispronunciation, inaccurate translation, and semantic distortions.

Furthermore, some studies indicated that Islamic terms' entries in English dictionaries have some distortions. Studies done by Al-Ajmi and Al-Otaibi (2006), Ali (2007), Abdurrosyid (2017) have shown that English dictionaries do not always provide objective and accurate material about cultural terms borrowed from other languages. As mentioned earlier, semantic studies of Islamic terms' entries in dictionaries have also indicated adaptation of lexical meanings in term of broadening, narrowing and shifting (Julul et al., 2019; Akidah, 2013; Danzaki, 2015). Al-Ajmi and Al-Otaibi (2006) have examined the entries of eight Islamic terms in three English dictionaries and have indicated a number of issues including circularity, insufficient information, negative contexts, very general definitions, ambiguity, incomplete information, narrow definitions and encyclopedic redundancy. For example, the term Islam is defined in Longman Dictionary of Contemporary English as "the Muslim religion, which was started by Muhammed and whose holy book is the Koran ..." where the definition is inaccurate 
and fails to be self-sufficient. Ali (2007) elaborates although many religions have founders, this is not the case in Islam. So, he suggested a more appropriate definition that would be "the religion which Muslims believe was revealed to the Prophet Muhammad" (p.33). Halal, a subject of investigation in this research, has been found to collocate mostly with food in most dictionaries causing lack of cohesive understanding of the term from an Islamic point of view (Al-Ajmi \& Al-Otaibi, 2006). In contrast, the term hijab is unlisted in English dictionaries (Abdurrosyid, 2017) despite its wide occurrences in published materials for mass readership (Al-Ajmi \& Al-Otaibi, 2006; Ali, 2014).

The significance of the current study lies in the point that Islamic terms have not previously been semantically analyzed, to the best of our knowledge, for their connotative meanings and the different associations they relay in the context of English language in use. Furthermore, connotative meanings of Islamic terms have not been previously compared with their denotative meanings in English. They have, however, been discussed in the context of translations of the Qur'an and Hadiths, or content analysis was performed on various genres to explore whether the terms concur with Muslims and Islam. Nonetheless, as English loanwords, Islamic terms have not received much attention or explanation. The current study examines three words that are becoming culturally shared. Since dictionaries are considered necessary in the translation task and as a documented guide for speakers of a given language, it is important to review their Islamic terminology entries in an effort to raise knowledge of different cultures and help promote successful intercultural communication.

\section{OBJECTIVES OF THE STUDY}

The objectives of this study are led by the following research questions:

1. What are the similarities and differences in the definitions of Islamic terms between English and Arabic dictionaries?

2. What are the semantic changes that occur to Islamic terms as loanwords in English dictionaries?

3. What are the connotations associated to them which may not be included in the dictionaries?

\section{THEORETICAL FRAMEWORK}

This study adopts semantic change analysis by Miller (2015) as a theoretical framework for data analysis. Lexical items are likely to undergo through specific mechanisms of meaning change which cause them to take on new meanings, disappear or being borrowed across languages, rather than senses being necessarily derived from central ones (Traore \& Natalia, 2016). Miller (2015) divided the semantic change into four types: extension, narrowing, semantic shift and metaphor. This approach has been used in previous semantic studies (see Akidah, 2013; Danzaki, 2015; Julul et al., 2019; Puspita \& Yusuf, 2020) and it is adopted here as it aligns with our research objectives. A number of terminologies are interchangeable to semantic extension such as generalization and broadening; and to narrowing such as restriction and specialization. Extension is a broadening of the old meaning where it becomes a subcase of the new one (Geeraerts, 2015). Whereas narrowing is when the word becomes less general. An example is the English term 'queen' which used to mean 'woman, wife' but the old meaning is restricted now to 'wife of a king' (Allan \& Robinson, 2011; Geeraerts, 2015). Semantic shift includes amelioration, when a word acquires positive or favorable meanings, and pejoration, 
when a word acquires negative associations (Katamba, 2005). The last type, metaphor, is when the word applies a meaning to something that it does not denote to point out similarity (Miller, 2015).

Since this work aims to investigate semantic change to Islamic terms in English dictionaries and language in use, two important aspects of word meanings are adopted, i.e. denotative and connotative meanings (Murphy, 2003). While denotative meaning refers to the dictionary, literal and cognitive meaning, connotative meaning refers to the expressive or emotive meaning (Dickins et al., 2016; Baker, 2018). Denotation provides the basic meaning of an expression that can be used in describing and categorizing an item; in contrast, connotation provides a meaning that is context dependent and includes the emotional and individual effects, it is changeable over time and not consistent as denotative meaning (Lyons, 1995; Bussman, 1996; Murphy, 2003). However, Baker (2018) pointed out that denotative meaning could also be judged as correct or incorrect while connotative meaning cannot since it is associated to speaker's emotions and attitudes.

\section{METHODOLOGY}

The terms investigated in this research, hijab, halal and islamist were chosen according to their usage, and they were of the most common Islamic terms in English as found in iWeb corpus (Davies, 2018). Their meanings in two English dictionaries were compared with their synonyms in an Arabic dictionary as well as to their Islamic definitions. Typically, speakers refer to the dictionaries to find the meaning of a given word, specifically those words they came across for the first time. Knowing the precise meaning of a given word would make it easier for the users to use that word in the correct sense by giving away the meaning it is meant to convey. Nonetheless, dictionaries do not explain the propositions constructed by words (Hanks, 2012).

In the present study, two research tools are used to analyze the data to better help answer the research questions. Three established dictionaries were included in this research: two English and one Arabic dictionary, in addition to quotations from iWeb corpus (Davies, 2018) to illustrate the use of these terms in English for communicative purposes.

\section{ENGLISH DICTIONARIES}

The online Collins English Dictionary (CED) (http://www.collinsdictionary.com) and Oxford Learner's Dictionaries (OLD) (https://www.oxfordlearnersdictionaries.com) are the English dictionaries chosen for this research. They are considered the best dictionaries used by both native and non-native speakers of English (Hanks, 2006). The CED compilation is based on synchronous principles and it provides the modern meaning of words. On the other hand, OLD focuses on etymological treatment of lexical items and is widely popular among speakers of English; it is certainly considered a credible guide for many users. Both dictionaries have electronic versions as well as hard copies (Hanks, 2006). We referred to each dictionary's website in this study to check for the definitions of the terms. Both were easily accessible and consistent in their presentation of the items, in addition to providing clear examples of sentences for each entry's possible contexts.

\section{ARABIC DICTIONARY}

In most Arabic dictionaries, entries are based on roots. In Arabic, the system of roots consists of the fundamental consonants; lexical items are formed from these roots by adding affixes, 
prefixes, vowels between the consonants, resulting in different word forms and meanings. An example is the root KTB from which different forms are inflected, the noun kita ${ }^{\wedge} b$ means 'book', kutub is the plural form 'books', $k a^{\wedge} t i b$ is the agentive noun means 'writer', the gerund kita 'bat 'writing', maktu' $b$ the perfect adjectival participle 'written', maktab the derivative noun meaning 'office', maktabat meaning 'libraries', and so on. In Arabic dictionaries, inflectional forms do not have separate root entries, but are classified as sub-entries under the fundamental verbal or nominal forms (El-Khattab, 2006).

A contemporary Arabic dictionary was used for the purpose of this study, $\mathrm{Al} \mathrm{Mu}$ 'jam Alwasit Dictionary (AAD), first compiled by the Academy of the Arabic Language in 1972. In this dictionary, lexical objects are grouped according to the alphabetical order of the roots. As a modern dictionary, it focuses on both the modern definitions of words and the idiomatic meanings of the words (El-Khattab, 2006). For the purpose of this study, we used an online version of AAD available at Almaany website (https://www.almaany.com) which is an encyclopedia with a strong selection of medieval and modern dictionaries (El-Khattab, 2006).

\section{EXTRACTS FROM WEBSITES}

Quotations were taken from the web using The Intelligent Web (Davies, 2018). iWeb corpus was released in 2018 and contains about 14 billion words in 22 million web pages in addition to other billion-word corpora from corpus.byu.edu. One of its advantages is that it allows users to create virtual corpora easily for the purpose of focusing on particular websites related to the user's areas of interest. iWeb is one of the only three more than 10 billion-word corpora which has very detailed information on syntactic, morphological, lexical and semantic variation in ways that would never be possible with a small 500 million word corpus. Furthermore, unlike other large web-based corpora where websites are essentially random, iWeb was created to select websites in a systemic way (Davies \& Kim, 2019; Davies, 2018).

iWeb also provides very rich collocational data for words which is not possible in other corpora. In Corpus of Contemporary American English (COCA), for example, there are only three noun collocates with 10 times or more occurrences i.e. skin, face, and marble. In the British National Corpus (BNC), however, there are no noun collocates with 10 times or more occurrences. Davies and Kim (2019) examined the iWeb for a mid-frequency example, Panini, which is word \#31,000 in the word frequency list and it has about 4280 times occurrences in the corpus. The total of noun collocates with seven times or more occurrences in iWeb is 106, which would be quite informative to investigate a word phenomenon. On the contrary, the same word panini has only three noun collocates that occur seven times or more in COCA, and none in the BNC (Davies \& Kim, 2019).

The current study aims to provide sample contexts of the use of our three selected Islamic terms to be compared with dictionary entries and examine the connotations associated to them which may not be included in the dictionaries. It will represent the reality of Islamic terms being used and the types of words with which they collocate. Frequency tool is also used to explore the terms' most frequent collocations and related topics.

\section{DATA ANALYSIS AND DISCUSSION}

The data discussed in this study consist of three English words related to Islam: hijab, halal, Islamist. The first stage in the inquiry about the data consisted of looking up the definitions of the target terms in both English and Arabic dictionaries i.e. denotative meanings. Arabic meanings were translated into the nearest synonyms in English. Both are listed in Table 1. 
As can be seen in Table1, the first lexical item hijab typically refers to head covering in English dictionaries. It seems to also denote face cover, as shown in the CED. OLD, however, extends the meaning to include the law of wearing hijab. The Arabic meaning of the term hijab is broader and denotes all kinds of covering. Nonetheless, as we are discussing the term in Islamic context, the two English dictionaries seem to complement each other in capturing the specific Islamic senses, especially in the OLD as in "religious system".

Similarly, with the term halal, OLD's denotative meaning is more comprehensive than the CED's, and it includes the broader meaning that covers all things that are "religiously acceptable" or "lawful". On the contrary, the senses of the second lexical item halal in CED is limited to food, meat in particular. Interestingly, adding English linguistic derivative suffixes $-s$, -ing, -ed changes the word class to become a verb.

Data of the third lexical item Islamist shows a huge contrast between its meaning in English dictionaries and the Arabic one. In Arabic, it is an adjective derived from the term Islam - the religion, meaning anything that advocates what is acceptable in the Islamic law. Yet, Islamist's senses in the English dictionaries stand for actions adhered to terrorism or extremism.

TABLE 1. Definitions of Islamic Terms in English and Arabic Dictionaries

\begin{tabular}{|c|c|c|c|}
\hline Terms & Collins Dictionary & Oxford Learner's Dictionaries & Al Mu'jam Alwasıt (Arabic) \\
\hline Hijab & $\begin{array}{l}\text { a covering for the head and } \\
\text { face, worn by Muslim women, } \\
\text { from Arabic, literally: curtain }\end{array}$ & $\begin{array}{l}\text { 1. a piece of clothing that covers the } \\
\text { head, worn in public by some } \\
\text { Muslim women } \\
\text { 2. the religious system that controls the } \\
\text { wearing of such clothing. }\end{array}$ & A covering. \\
\hline Halal & $\begin{array}{l}\text { 1. meat from animals that have } \\
\text { been killed according to } \\
\text { Muslim law (noun). } \\
\text { 2. of or relating to such } \\
\text { meat } \Rightarrow \text { a halal butcher } \\
\text { (adjective) } \\
\text { 3. Suffixes }-s \text {, -ing, -ed, to kill } \\
\text { (animals) in this way (verb) }\end{array}$ & $\begin{array}{l}\text { 1. (of meat) from an animal that has } \\
\text { been killed according to Muslim law } \\
\text { 2. acceptable according to Muslim } \\
\text { religious law (adjective) }\end{array}$ & Permissible \\
\hline Islamist & $\begin{array}{l}\text { 1. supporting or advocating } \\
\text { Islamic fundamentalism } \\
\text { (adjective) } \\
\text { 2. a supporter or advocate of } \\
\text { Islamic fundamentalism } \\
\text { (noun) }\end{array}$ & $\begin{array}{l}\text { a person who believes strongly in the } \\
\text { teachings of Islam. (noun) }\end{array}$ & $\begin{array}{l}\text { Adjective from Islam } \\
\text { 1. Submission to God. } \\
\text { 2. The religion which } \\
\text { Prophet Mohammad } \\
\text { (peace be upon him) } \\
\text { was sent to convey. }\end{array}$ \\
\hline
\end{tabular}

The second stage in investigating the meaning of Islamic lexical terms in English consists of exploring the connotative meanings of the three targeted items hijab, halal, Islamist in language in use.

Based on the data from iWeb corpus (Davies, 2018), the selected lexical items are of the mid-frequent words in the corpus. The first lexical item hijab, which is word \#23339 has 10786 times occurrences in the corpus, more than double times occurrences of the term panini (Davies \& Kim, 2019). The data from iWeb frequency tool shows the topics consistently associated with hijab: Muslim, wear, woman, Islamic, religious, scarf, headscarf, dress, mosque. The findings show that the most common connotation of hijab is taken to refer only to head cover as the following extracts illustrate: 
1) "She may want to consider what material she is using for her hijab. Cotton, polyester and other similar materials can contribute to drying the hair out." (blacknaps.org)

2) "... of Muslim women who claim they were discriminated against by their employers for wearing a hijab, or headscarf, to work. Three recent decisions provide insight on the attitude ..." (littler.com)

3) "This means that all female students would be required to wear the hijab or niqab which cover their heads and faces." (gatestoneinstitute.org)

4) "... capital and boys and girls attend separate schools. While most women wore a simple hijab a scarf worn over the head I did see plenty of burkas, which cover ..." (gjsentinel.com)

5) "... ability, to dive into the sport; and Rahaf Khatib, the first Muslim hijabi runner to ever appear on the cover of a major fitness magazine." (baa.org)

6) "... that and compliment me on it. Stores like H\&M and Charlotte Russe are also hijabifriendly most of the time. Maxi dresses and skirts are a hijabi's best friend ..." (wehavekids.com)

It is quite obvious that the concept of hijab as a head cover is retained in English in use and coincides with English dictionaries as in 1 and 2. Examples 3 and 4 show clearly how English in use differentiate between hijab as headscarf and other forms of covering for Muslims as niqab or burka. Although dictionaries include other senses for the term i.e. face cover and religious code, the concept is restricted, to some extent, in communication to only one. However, the fact that language changes and develops through the use of its speakers, this explains the high occurrence of the most common adjective derived from the term hijab, hijabi as in 5, and the relatively new expression hijabi-friendly as in 6-showing the tendency for the concept to expand to include women's wear as well. It is interesting to note that hijab takes a suffix $-i$ to refer to one who customary wears hijab, which is referred to in Arabic by the word muhajaba.

A documentary article in the religion section on the British Broadcast Corporation (BBC) website illustrates the broad meaning of hijab: "an Arabic word, meaning barrier or partition. In Islam, however, it has a broader meaning. It is the principle of modesty and includes behavior as well as dress for both males and females" (BBC, 2020). There is no fixed standard to its style or type of cloth rather than some requirements that have to be met regarding the parts of body that must be covered, looseness, thickness and appearance (www.iiie.net).

The second lexical item is halal, another word that is becoming more common in English speaking communities. It is word \#22312 and has 11640 times occurrences in the corpus, a very close occurrence to hijab. The extracts show that the most connotation of halal is mainly taken to refer to food as in 1, 2, 5, 6 in addition to little use in the context of commerce and trading as in 4, 6, 7. The data from iweb frequency tool shows the topics consistently associated with halal: Muslim, Islamic, meat, food, kosher, religious, animal, chicken.

1) "Teriyaki Experience, Extreme Pita, Williams Fresh Cafe and much more. \# Offering Halal, vegan or vegetarian options, we are committed to providing food that meets the" (humber.ca)

2) "Searcys will provide catering. Halal and Kosher catering is available upon request. A sumptuous three course menu is 58+VAT" (hirespace.com)

3) "... Hajj with it. This is because the performance of Hajj requires pure/good earnings from Halal sources, however, if he has already performed Hajj, then his Hajj is" (justaskislam.com) 
4) “... is not Haram essentially. I don't know This kind of trading is not Halal because of what I mentioned. In my country Crash. \# At home job" (globalcache.com)

5) "Naturally I was amused at the thought of chicken being halal-friendly, when it is either halal or it isn't. \# My colleagues were" (the-platform.org.uk)

6) "By making some small changes in store on request, you can now halalify your very own gourmet burger to suit your needs. Were happy to cook your" (burgerfuel.com)

7) "... demand for vegetarian products together with the fact that all Anlit products are certified kosher and halalled the company to replace gelatin with pectin." (preparedfoods.com)

In English, the term was typically used in reference to Muslim food laws only, especially with meat, but it seems that the concept of halal has started broadening in different ways to include not only food but other aspects of life. English verbal derivational suffixes, -ed, -ify and others are also added to the term halal to alter the word class into a verb as in examples 6 and 7.

However, the concept in English is still narrow compared to the broader Islamic meaning, which is lawful as opposed to unlawful and refers to permissible behavior, speech, dress, conduct, manner and dietary, every aspect of a Muslim's life is measured by Islamic law one of which is, the Halal-Haram dichotomy (www.iiie.net).

Our third lexical item, Islamist, is perhaps the most controversial since it has been used to label Muslims who proclaim Islam as the source of their political and social action. Indeed, Islamist, is a semantically complicated term. It is word \#15407 and has 25890 times occurrences in the corpus, even more frequent than the two previously discussed terms. According to Kramer (2003) and Mozaffari (2007), the lexical item Islamism was first used by French to refer to Islam the religion of the Muslims without any political or ideological connotations; Islamist was used to refer to Muslims whose religion is Islam. By the beginning of the twentieth century, however, it started to vanish and was replaced by simple Islam, a term that has neither pejorative nor comparative connotations (Kramer, 2003). Later on, Kramer (2003) elaborates the expression Islamic fundamentalism started to appear in parallel to Christian fundamentalism, which was first established in America by protestant Christians who felt challenged by the higher criticism of the Bible and called themselves "fundamentalists"; the term is strongly pejorative and equated to extremism. In order to name some movements in the Islamic world, the term Islamism returned to be used in French again, and subsequently was loaned into English (Mozaffari, 2007). Furthermore, Islamist was later used to characterize Muslims with political agendas, both moderate and peaceful as well as intolerant. Both words Islamism and Islamist have been associated with terrorism and negative connotations as a result of violence perpetrated by extremist Muslims.

As discussed above, the term Islamist is synonymous in English dictionaries with Islamic movements that favor strict observance and connected to fundamentalism. When the word is translated into Arabic, the synonym is Islami, which is an adjective from Islam. Thus, in looking up the definition in Arabic dictionaries, we looked up the word Islam. According to $\mathrm{AAD}$, the word was derived from Arabic root silm, which means peace, and submission. Islam was constantly referred to as the religion of Islam in AAD. The Islamic definition of Islam means:

\footnotetext{
"Submission to the One God and living in peace with the Creator. It means living in peace with one's self, with other people, and with the natural environment. A Muslim is supposed to live in peace and harmony with all these segments. Hence, a Muslim is any person anywhere in the world whose obedience, allegiance, and loyalty are to God, the Lord of the Universe, and to the innate harmony of His Creation. Thus, Islam is a total system of living." (www.iiie.net)
} 
A significant point to address here is that both English terms Islamism and Islamist seem to be derived from the word Islam by adding derivative suffixes -ism, meaning the action, process, result, and -ist, meaning a person who performs a certain action. Islam is known as the religion of Muslims, but it is erroneously possible to add to Islam any connotations attached to derivations of the term Islam. Negative connotations are associated to both terms, Islamist and Islamism, as shown in the following extracts from iWeb corpus.

1) "Bosnia and Herzegovina and the Nexus with Islamist Extremism (2015); The Lure of the Syrian War: The Foreign Fighters ..." (rusi.org)

2) "...the thread of the case, it slowly unravels into a longer story involving an Islamist group, property development, and drug dealing. As it turns out "would" (culturewhisper.com)

3) "Thus, they called for the unveiling of women. The Islamist rulers of Iran argue the same point in justifying their violent reimposition of the veil" (centerforinquiry.net)

4) "I foresee the Soviets really focusing on getting rid of the Islamist government and replacing it with that popular Front I mentioned." (alternatehistory.com)

5) "Maassen warned that an Islamist or right-wing attack in Germany could lead to an explosion of social unrest." (armstrongeconomics.com)

6) "David Cameron said the government is considering placing all convicted Islamist terrorist prisoners in England and Wales in a single secure unit in order to prevent ..." (gatestoneinstitute.org)

The data from iWeb frequency tool also shows the topics consistently associated with Islamist: Islamic, Muslim, attack, terrorism, terrorist, military. These are also similar to the topics associated to Islamic: Muslim, attack, religion, terrorism, terrorist, military. Although Islamic is derived from Islam and Islamist from Islamism, it is obvious that they have quite close meanings in English in use. These findings are consistent with other studies where Islamic was shown to carry extremely negative discourse prosody and to be associated with religious and political extremism, militancy and terror in social media and news discourse (Törnberg \& Törnberg, 2016).

The above findings show that the denotative and connotative meanings of hijab and halal have been narrowed. This resonates with the findings of Julul et al. (2019) that narrowing is the most dominant semantic change to Arabic loanwords in Indonesian and Malay. Furthermore, most of the polysemous Arabic loanwords that have one meaning related to Islamic religion have retained the religious meaning while other senses were lost. Similarly, Danzaki's (2015) investigation of Arabic words loaned into Hasua has shown that borrowed words in the recipient language were restricted to only one particular meaning such as the word tahiya which means greeting in Arabic that applies to many contexts but in Hausa it is restricted to Muslims' prayers.

Narrowing and expansion in meaning of loanwords can occur due to either generalization of restricted sense or restriction of a generalized sense (Danzaki, 2015). Studies have suggested that narrowing occurs when words are loaned, and a number of expansion and semantic shifts can happen to the meaning within the recipient language. This explains the additional contexts in which the terms halal and hijab are used in the recipient language English in this study. The meaning has been narrowed-although expressions such as 'hijabi-friendly stores', 'halalfriendly chicken' and 'to halalify your burger' are not used in Arabic, they have started to occur in English. These occurrences support the hypothesis that words are loaned first when the recipient language lacks a word to express a particular concept, and then they start to extend the loanwords to adapt to the society's needs using that language (Haspelmath \& Tadmor, 
2009; Danzaki, 2015; Julul et al., 2019) as they become more common and more accepted as part of the lexicon (Miller, 2015).

Our findings show a semantic shift in the denotative meaning of the word Islamist both in CED and the connotative meaning in the use of the word, yet this meaning totally contradicts with its definition in OLD. Julul et al. (2019) posit that in the process of adaptation to the recipient language, a complete shift of meaning can occur with the word taking on a new meaning that is totally irrelevant to the original one, and this change usually happens over a period of time especially in borrowing specific cultural terms. Specifically, they explained that when two words have the same root in the donor language, it is possible for them to have the same meaning when loaned into the recipient language, such as adan meaning paradise, and adnan that is a proper name in Arabic. In Indonesian, both words adan and adnan mean paradise. However, the case of Islamist as shown in this study has developed pejorative senses, different from the term Islam which means the religion of Muslims. Thus, even though both terms have the same root, they have totally different meanings. Wakefield (2018) gives the example of semantic shift that leads to negative connotations for the loanword $k u l$ in Cantonese which was borrowed from English word cool. The word in English means a compliment while the loanword $k u l$ in Cantonese developed a pejorative meaning to mean a person who is distant or unfriendly.

Findings of this study are consistent with other studies (Al-Ajmi \& Al-Otaibi, 2006; Ali, 2007; Abdurrosyid, 2017) showing that English dictionaries are sometimes inconsistent in capturing the senses of Islamic concepts as in the case of hijab and halal, yet one can refer to more than one dictionary for a comprehensive insight into the meaning. The different meanings of words in English dictionaries from the Arabic ones can be a result of the use of lexical items in communication which cause them to acquire different connotations and gradually to become their typical definition. The lack of comprehensive or accurate understanding of Islamic terms may have been one of the contributing reasons to Islam being represented as irrational, antiquated, extremist and lacking democracy (Moore et al., 2008; Baker et al., 2013). One of the reasons for the negative connotations associated to Islamist might be the media coverage that represents Islam as dangerous and the regular portrayal of Muslims with situations of conflict and violence. Moore et al. (2008) aptly observes that media credence is powerful that "journalists may have more influence than ordinary people upon a dominant public discourse" (p.7). Indeed, results from this study also have suggested that the media discourse might have more influence on words' definitions than other forms of communication.

\section{CONCLUSION}

This study aims to explore the semantic change in denotative and connotative meanings of Islamic terms in English, derived from the understanding of the value of words as instruments of communication and how their usage affects our communities and attitudes within themselves. Words that develop associated meanings, notwithstanding the problem of untranslatability, different from the donor culture could easily give rise to cross-cultural misunderstanding. The meanings of three common words related to Islam hijab, halal and Islamist have gone through semantic change in terms of narrowing, context expansion and pejoration.

Our investigation has shown that Islamic terms majorly retained their Arabic meaning in English. Although narrowing was the major semantic change that have happened to the words, their connotative meanings seem to expand and include other contexts different from the original ones. However, it is impossible to make conclusions about why these semantic changes 
and distortion of meanings occurred. It might be a reflection to changes in the use of Islamic terms in Arabic and among Muslim communities on global and national levels such as the term Islamist, but this is beyond the scope of this study as we did not compare the meaning in Arabic dictionaries with Arabic language in use.

Nonetheless, it is clear that the use of language for communication can have a huge impact on loanwords. Obviously, the use of transliteration strategy does not guarantee save culturally specific items from change and meaning distortion. Language in use may have a stronger impact on words' meanings and lead them to acquire neutral or negative English denotative and connotative meanings. Although this is not always evident in the data of dictionaries, these connotative meanings are much apparent in the usage of the words, communicatively. The current study has shown that the term Islamist has gained negative connotations while the concept of hijab and halal have been narrowed. In other words, their definitions have been restricted to fewer senses than the broader Arabic terms.

Furthermore, there remains inconsistency in defining these terms among English dictionaries. The results have shown that there is a vague interpretation of Islamic culture that results in inaccurate definitions of borrowed terms. Restricted meanings of Islamic specific terms may result in limited understanding of Islamic culture that leads to the view of its members as homogenous entities while neglecting the fact that Muslims come from various cultural backgrounds (Baker et al., 2013). Thus, this research suggests that there is still room for further work related on meaning transfer of cultural specific terms and Islamic terms in particular in order to achieve semantic justice to these terms and to accomplish successful intercultural communication.

The study was obviously limited to a small number of lexical items; further research therefore is recommended to look at a larger variety of Islamic terms that have been borrowed and used widely in the English language. Nonetheless, it is pioneering in investigating semantic change of Islamic terms' entries in English dictionaries and comparing them with their English in use. It is also the first to shed light on semantic change of loaned Islamic terms in English and mark some distortions to the original meanings.

\section{ACKNOWLEDGEMENT}

We acknowledge critical comments received from anonymous reviewers to improve the paper.

\section{REFERENCES}

Abdul-Ghafour, A. Q. K. M., Awal, N. M., Zainudin, I. S., and Aladdin, A. (2019). The interplay of Qur'ānic synonymy and polysemy with special reference to Al-asfār and Al-kutub (the Books) and their English translations. 3L: Language, Linguistics, Literature. 25(1). http://dx.doi.org/10.17576/3L-2019-2501-10

Abdurrosyid, A. (2017). The Islamic entries in three major English dictionaries. Insaniyat: Journal of Islam and Humanities. 2(1), 41-49. http://dx.doi.org/10.15408/insaniyat.v2i1.6588

Agliz, R. (2015). Translation of religious texts: Difficulties and challenges. Arab World English Journal (AWEJ) Special Issue on Translation. 4.

Akidah, M. A. (2013). Phonological and semantic change in language borrowing. International Journal of Education and Research. 1(4), 1-20.

Al-Ajmi, H. \& Otaibi, A. (2006). The treatment of terms relating to Islam and the Arab world in English dictionaries. LEXIKOS: African journals online. 16. https://doi.org/10.5788/16-0-645

Al-Azzam, B. (2005). Certain terms relating to Islamic observances: Their meanings with reference to three translations of the Qur'an and a translation of Hadith. PhD Thesis, Durham University. http://etheses.dur.ac.uk/1775/

Al-Faruqi, I. R. (1995). Toward Islamic English. Herndon: International Institute of Islamic Thought.

Alghamdi, R. S. (2016). Translating religious terms and culture in "The Sealed Nectar": A model for quality assessment. PhD Thesis, University of Leeds, Leeds.

Al-Mu‘jam Alwasit. (n.d.). In Almaany.com. Retrieved June 10, 2020, from https://www.almaany.com 
Aldahesh, A.Y. (2014). (Un)Translatability of the Quran: A theoretical perspective. International Journal of Linguistics. 6(6), 23-45. https://doi.org/10.5296/ijl.v6i6.6497

Ali, H. M. B. M. (2007). Islamic terms in contemporary English. English Today. 23(2), 32. https://doi.org/10.1017/S0266078407002064

Ali, H. M. B. M. (2009). Islamic terms in English usage. Language in India. 9, 76-102.

Ali, H. M. B. M. (2014). Islamo-English: A variety of English for the Ummah. Research Journal of English Language and Literature. 2(3), 68-75.

Allan, K. \& Robinson, A. J. (Eds.). (2011). Current methods in historical semantics. Berlin: Mouton de Gruyter.

Anwar, F. (2017). Semantic change in language borrowing: The case of Arabic borrowed words in Urdu. Language in India. 17(2), 107-124. http://languageinindia.com/feb2017/farheenurdusemanticsfinal.pdf

Awan, I. (2016). Virtual Islamophobia: the eight faces of anti-muslim trolls on Twitter. In Awan, I. (Ed.). Islamophobia in Cyberspace: Hate Crimes Go Viral. (pp. 23-40). New York: Routledge.

Baker, M. (2018). In other words: A coursebook on translation (3rd ed.). New York: Routledge.

Baker, P., Gabrielatos, C. \& McEnery, T. (2013). Discourse analysis and media attitudes: The representation of Islam in the British press. Cambridge: Cambridge University Press.

British Broadcast Corporation. (2020). Hijab. Retrieved July 1, 2020 from http://www.bbc.co.uk/religion/religions/islam/beliefs/hijab_1.shtml on July, 2020

Bussman, H. (1996). Dictionary of language and linguistics. London: Routledge.

Collins English dictionary. (n.d.). In collinsdictionary.com. Retrieved June 10, 2020 from http://www.collinsdictionary.com

Cruse, D. A. (2000). Meaning in language: An introduction to semantics and pragmatics. Oxford: Oxford University Press.

Daghoughi, S. \& Hashemian, M. (2016). Analysis of culture-specific items and translation strategies applied in translating Jalal Al-Ahmad's 'By the Pen'. English Language Teaching. 9(4), 171-185. http://dx.doi.org/10.5539/elt.v9n4p171

Danzaki, M. A. (2015). Semantic change in Arabic loanwords in Hasua. Proceedings of the 2nd International Conference on Arabic Studies and Islamic Civilization. http://dx.doi.org/10.20473/mozaik.v19i2.14584

Davies, E. E. (2003). A goblin or a dirty nose? The treatment of culture-specific references in translations of the Harry Potter books. The Translator. 9 (1), 65-100. https://doi.org/10.1080/13556509.2003.10799146

Davies, M. (2018). The iWeb Corpus. Retrieved June 10, 2020 from https://www.english-corpora.org/iWeb/

Davies, M. \& Kim, J. B. (2019). The advantages and challenges of "big data": Insights from the 14 billion word iWeb corpus. Linguistic Research. 36(1), 1-34. http://dx.doi.org/10.17250/khisli.36.1.201903.001

Dickins, J., Hervey, S. \& Higgins, I. (2016). Thinking Arabic translation: A course in translation method: Arabic to English (2nd ed.). New York: Routledge.

El-Khattab, D. (2006). Arabic lexicography. In Brown, K. (Ed.), Encyclopedia of language and linguistics. (2nd ed.) (Vol. 13). (pp. 441-443). Oxford: Elsevier.

El-Shiekh, A. \& Saleh, M. (2011). Translation versus transliteration of religious terms in contemporary Islamic discourse in western communities. International Journal of English Linguistics. 1(2), 141-147. http://doi.org/10.5539/ijel.v1n2p141

Farahani, M, V. \& Mokhtari, A. (2016). An analysis of cultural specific items in English translation of Hedayat's "Blind Owl" based on domestication vs. foreignization Dichotomy. Journal of Applied Linguistics and Language Research. 3(4), 308-324. http:/www.jallr.com/index.php/JALLR/article/view/371/pdf371

Geeraerts, D. (2015). Lexical semantics. In D.A. Cruse (Ed.). International Encyclopedia of the Social \& Behavioral Sciences (2nd ed.). (pp. 8758-8764).

Ghazala, H. (2002). Tarjamatul mustalahatil Islamiati. Paper presented at the Symposium on the Translation of the Holy Quran. Al-Madinatul Munawwaratu: Kingdom of Saudi Arabia.

Hanks, P. (2006). Lexicography overview. In Brown, K. (Ed.). Encyclopedia of language and linguistics (2nd ed.). (Vol .13). (pp.113-128). Oxford: Elsevier.

Hanks, P. (2012). How people use words to make meanings: semantic types meet valences. In Boulton, A. \& Thomas, J. (Eds.). Input, process and product: Developments in teaching and language corpora. (pp. 5469). Brno: Masaryk University Press.

Haspelmath, M. \& Tadmor, U. (2009). Loanwords in the world's languages: A comparative handbook. Berlin: Walter de Gruyter.

Hassan, S. (2016). Islamic religious terms in English-translation vs. transliteration in Ezzeddin Ibrahim and Denys Johnson-Davies' translation of An-Nawawi's Forty Hadiths. Translation \& Interpreting. 8(1), 117-132. http://dx.doi.org/10.12807/ti.108201.2016.a08

Institute of Islamic Information and Education. Retrieved July 1, 2020 from http://www.iiie.net/

Jasper, D. (Ed.). (1993). Translating religious texts: Translation, transgression and interpretation. New York: St Martin's Press. 
Julul, A. A., Rahmawati, N. M., Kwary, D. A. \& Sartini, N. W. (2019). Semantic adaptations of the Arabic loanwords in the Indonesian language. MOZAIK HUMANIORA. 19(2), 135-147.

Kashgary, A. D. (2011). The paradox of translating the untranslatable: Equivalences. non-equivalence in translating from Arabic into English. Journal of King Saud University-Languages and Translation. 23, 47-57. http://dx.doi.org/10.1016/j.jksult.2010.03.001

Katamba, F. (2005). English words (2nd ed.). London: Routledge.

Kramer, M. (2003). Coming to terms: Fundamentalists or Islamists? Middle East Quarterly. 10(2), 65-77.

Larson, R. (1988). On the double object construction. Linguistic Inquiry. 19, 335-391.

Liddicoat, A. J. (2009). Communication as culturally contexted practice: A view from intercultural communication. Australian Journal of Linguistics. 29(1), 115-133. http://dx.doi.org/10.1080/07268600802516400

Leech, G. (1981). Semantics. Harmondsworth: Penguin Books.

Leskovar, D. M. (2017). Names in literary translation: A case study of English versions of the Slovenian tale Martin Krpan. Acta Neophilologica. 137-152. https://doi.org/10.4312/an.50.1-2.137-152

Lyons, J. (1995). Linguistics semantics: An introduction. Cambridge: Cambridge University Press.

Miller, R. (2015). Trask's historical linguistics. New York: Routledge.

Moore, K., Mason, P. \& Lewis, J. (2008). Images of Islam in the UK: The representation of British Muslims in the national print news media 2000-2008. Cardiff: Cardiff University.

Mozaffari, M. (2007). What is Islamism? History and definition of a concept. Totalitarian movements and political religions. 8(1), 17-33. https://doi.org/10.1080/14690760601121622

Murphy, M. L. (2003). Semantic relations and the lexicon: Antonymy, synonymy and other paradigms. New York: Cambridge University Press.

Newmark, P. (1988). Approaches to translation. Hertfordshire: Prentice Hall.

Newmark, P. (1995). A textbook of translation. London: Phoenix ELT.

Oboler, A. (2016). The normalisation of Islamophobia through social media: Facebook. In Awan, I. (Ed.). Islamophobia in Cyberspace: Hate Crimes Go Viral. (pp. 41-62). New York: Routledge.

Oxford Learner's Dictionaries. (n.d.). Retrieved June 10, 2020 from https://www.oxfordlearnersdictionaries.com

Öztemel, F. \& Kurt, M. (2017). Transmission of cultural specific items into English translation of "Dear Shameless Death” by Latife Tekin. International Journal of Languages, Education and Teaching. 5(1), 302-320. http://doi.org/10.18298/ijlet.1678

Puspita, D. \& Yusuf, K. (2020). Sketching the semantic change of Jahanam and Hijrah: A corpus based approach to manuscripts of Arabic-Indonesian Lexicon. Arabi: Journal of Arabic Studies. 5(1), 1-10. http://dx.doi.org/10.24865/ajas.v5i1.246

Saeed, J. (2015). Semantics. International Encyclopedia of the Social \& Behavioral Sciences. 21(2), 585-591. http://dx.doi.org/10.1016/B978-0-08-097086-8.53079-7

Simbuka, S., Hamied, F. A., Sundayana, W. \& Kwary, D. A. (2019). A corpus-based study on the technical vocabulary of Islamic religious studies. Teflin Journal. 30(1), 47-71. http://dx.doi.org/10.15639/teflinjournal.v30i1/47-71

Törnberg, A. \& Törnberg, P. (2016). Muslims in social media discourse: Combining topic modeling and critical discourse analysis. Discourse, Context \& Media. 13, 132-142. http://dx.doi.org/10.1016/j.dcm.2016.04.003

Wakefield, J.C. (2018). Turning English into Cantonese: The semantic change of English loanwords. In Polley J., Poon, V. \& Wee, LH. (Eds.). Cultural conflict in Hong Kong. Singapore: Palgrave Macmillan. https://doi.org/10.1007/978-981-10-7766-1_2

Wright, S. E. \& Budin, G. (1997). Handbook of terminology management. Philadelphia: John Benjamins.

Yahya, Y. (2018). Lexemes mean God in Al-Qur'an and Arabic Gospel: semantic analysis. LISANUDHAD. 5(2), 105-126. http://dx.doi.org/10.21111/lisanudhad.v5i2.2602

Yulianita, N. G., Nababan, M. \& Djatmika, D. (2018). The acceptability of religious terms translation in the 'Complete Idiot's Guide to Understanding Islam'. Lingua Cultura.12(2), 111115.http://dx.doi.org/10.21512/lc.v12i2.3999 